"Mircea cel Batran" Naval Academy Scientific Bulletin, Volume XIX - 2016 - Issue 1

Published by "Mircea cel Batran" Naval Academy Press, Constanta, Romania // The journal is indexed in:

PROQUEST / DOAJ / DRJI / JOURNAL INDEX / I2OR / SCIENCE LIBRARY INDEX / Google Scholar / Crossref /

Academic Keys I ROAD Open Access / OAJI / Academic Resources / Scientific Indexing Services / SCIPIO

\title{
INFLUENCE OF PROPRIOCEPTIVE TRAINING ON THE STRENGHT OF THE LOWER LIMB IN WOMEN SOCCER PLAYERS
}

\author{
Diana Victoria GIDU ${ }^{1}$ \\ ${ }^{1}$ Lecturer PhD Faculty of Psysical Education ans Sports, Ovidius University of Constanta, \\ campiap@yahoo.com
}

\begin{abstract}
The proprioceptive training has an important role in developing and maintaining the force of the lower limbs. The proprioceptive training rapidly gained attention in the sport performance for both the prevention and recovery of muscular injuries and increasing physical performance.

Purpose: The aim of this study was to prove that a 15 minutes of proprioceptive training performed at the beginning of the training sessions has a good influence on force of the lower limb in women soccer players.

Material and methods: Participants were 18 active women soccer players, age $20.75 \pm 4.59$ years old. The task of the experimental group consisted to performed a 15 minutes of proprioceptive exercises, special designed for soccer game, at the beginning of the training sessions, two times a week. For the measurement of the forces of the lower limbs we used Hop test.

Conclusions: The experimental group has recorded better results than the control ones, on the Hop test $(p<$ 0,005).
\end{abstract}

Key words: proprioceptive exercises, women soccer players, increase force, lower limbs.

\section{Introduction}

The proprioceptive training plays an important role in developing and maintaining the force of the lower limbs. Most researches have proved that the proprioceptive exercises are the ones that can be very important in the training sessions. Myer, G.D. et all., 2005 and Zouita Ben Moussa et all., 2009 claim that soccer women that includes in their training even proprioceptive exercises will benefit in terms of strength and neuromuscular control, and in increasing the dynamic stability of the joints.

The proprioceptive or neuromuscular training rapidly gained attention in the sport performance for both the prevention and recovery of muscular injury and in increasing physical performance (Gidu, D.V., Oltean, A., 2016; http://www.scribd.com/doc/227803314/Prezentare -Pitesti-Ro\#scribd).

Proprioceptive training technique is based on easy and controlled stress applied to the joints by using exercices that are made on instabile surfaces (bossu balls, plăci de echilibru etc). The exercices used in this type of training aim at stimulating proprioceptive systems and the nervous centers wich are responsible for postural balance control (R. Cocucci, R. Boni, 2005). So, the proprioceptive training must be planed in such a way that will cause the athlete to lose balance, to activate promptly and in an appropriate manner muscles that are involved, and increase the muscle strength, respectively (http://www.my-

personaltrainer.it/allenamento/allenam ento-propriocettivo.html).

An important effect of these exercises is to develop strength parameters (http://www.scribd.com/doc/227803314/Prezentare -Pitesti-Ro\#scribd).

Hypothesis We supposed that 15 minutes of proprioceptive exercises, specially designed for soccer game, performed at the beginning of the training sessions, two times per week, has a good influence on force of the lower limb in women soccer players.

Material and methods. Participants were 18 active women soccer players, age $20.75 \pm 4.59$ years old. The task of the experimental group consisted in performing a 15 minutes of proprioceptive exercises, specially designed for soccer game, at the beginning of the training sessions, two times per week. For the measurement of the forces of the lower limbs we used Hop test. The Hop test consists of five kinds of jumping, as follows: S1 - vertical jump; S2 - hop for distance; S3 - drop jump followed by a double hop for distance; S4 - square hop; S5 - side hop. In this paper we tested only the S2 and S5. For each components was tested both legs.

Results The results on the Hop test - the strenght of the lower limbs, respectively S2 and S5, in the both, experimental and control groups, are presented in the Table no 1. 
"Mircea cel Batran" Naval Academy Scientific Bulletin, Volume XIX - 2016 - Issue 1

Published by "Mircea cel Batran" Naval Academy Press, Constanta, Romania // The journal is indexed in: PROQUEST / DOAJ / DRJI / JOURNAL INDEX / I2OR / SCIENCE LIBRARY INDEX / Google Scholar / Crossref /

Academic Keys I ROAD Open Access / OAJI / Academic Resources / Scientific Indexing Services / SCIPIO

Table no 1: The results on the Hop test.

\begin{tabular}{|c|c|c|c|c|c|}
\hline \multirow{2}{*}{\multicolumn{2}{|c|}{ Statistical parameters }} & \multicolumn{4}{|c|}{ Initial testing } \\
\hline & & \multicolumn{2}{|c|}{ S2 (s) } & \multicolumn{2}{|c|}{ S5 (s) } \\
\hline Stalistical pa & & $\begin{array}{l}\text { Left } \\
\text { leg }\end{array}$ & $\begin{array}{c}\text { Right } \\
\text { leg }\end{array}$ & $\begin{array}{l}\text { Left } \\
\text { leg }\end{array}$ & $\begin{array}{c}\text { Right } \\
\text { leg }\end{array}$ \\
\hline \multirow{3}{*}{$\begin{array}{l}\text { Experimental } \\
\text { goup }\end{array}$} & $\mathrm{X}$ & 145.17 & 148.75 & 22.25 & 23.83 \\
\hline & $\pm \mathrm{DS}$ & \pm 7.99 & \pm 7.33 & \pm 1.71 & \pm 1.40 \\
\hline & CV\% & 5.51 & 4.93 & 7.69 & 1.18 \\
\hline \multirow{8}{*}{$\begin{array}{l}\text { Control } \\
\text { group }\end{array}$} & $\mathrm{X}$ & 147.33 & 148.17 & 23.00 & 23.66 \\
\hline & $\pm D S$ & \pm 9.15 & \pm 9.02 & \pm 1.41 & \pm 0.81 \\
\hline & CV\% & 6.21 & 6.08 & 6.14 & 3.44 \\
\hline & $t$ & 0.493 & 0.137 & 0.987 & 0317 \\
\hline & p & $>0.05$ & $>0.05$ & $>0.05$ & $>0.05$ \\
\hline & & \multicolumn{4}{|c|}{ Final testing } \\
\hline & & \multicolumn{2}{|c|}{ S2 (s) } & \multicolumn{2}{|c|}{ S5 (s) } \\
\hline & & $\begin{array}{l}\text { Left } \\
\text { leg }\end{array}$ & $\begin{array}{c}\text { Right } \\
\text { leg }\end{array}$ & $\begin{array}{l}\text { Left } \\
\text { leg }\end{array}$ & $\begin{array}{l}\text { Right } \\
\text { leg }\end{array}$ \\
\hline \multirow{3}{*}{$\begin{array}{l}\text { Experimental } \\
\text { goup }\end{array}$} & $\mathrm{X}$ & 150.50 & 157.00 & 24.41 & 25.16 \\
\hline & \pm DS & \pm 6.58 & \pm 5.11 & \pm 0.79 & \pm 1.40 \\
\hline & CV\% & 4.40 & 3.25 & 3.24 & 5.56 \\
\hline \multirow{5}{*}{$\begin{array}{l}\text { Control } \\
\text { group }\end{array}$} & $\mathrm{x}$ & 145.00 & 147.00 & 23.16 & 24.00 \\
\hline & $\pm \mathrm{DS}$ & \pm 6.06 & \pm 9.61 & \pm 1.16 & \pm 0.89 \\
\hline & CV\% & 4.18 & 6.53 & 5.04 & 3.72 \\
\hline & $t$ & 2.441 & 2.385 & 2.362 & 2.141 \\
\hline & p & $<0.05$ & $<0.05$ & $<0.05$ & $<0.05$ \\
\hline
\end{tabular}

\section{Discussions}

In S2 - hop for distance test, the experimental group obtained significant better performances in the final testing, for both, left $(t=5.686, p<$ $0.001)$ and right leg $(t=4.27, p<0.001)$.

Comparison of the results of the two groups, proves that the experimental group obtained significant better results in the final testing, both in the left and the right leg $\left(t_{l}=2.441 ; t_{r}=2.385\right.$, $\mathrm{p}<0.05)$.

Chappell, J.D., Limpisvasti, O., 2008, claim that „a 6-week neuromuscular training program significantly improved athletic performance on jump tests"

At S5 - side hop, the experimental group obtained significant better results in the final testing, for both, left $(t=4.733, p<0.001)$ and right leg $(t=4.690, p<0.001)$.

Comparison of the results of the two groups shows that the experimental group recorded significantly better results in the final testing, both in the left and the right leg $\left(t_{1}=2.362 ; t_{r}=2.141\right.$, $p<0.05$ ).
Our results confirm the data registred by others researchers - Gustavsson, A., et all., 2006, Coughlan, G., Caulfield, B., 2007, Barton Straus, L., 2012 who consider that a single leg exercises, on unstable surfaces - Bossu balls - improve proprioceptivity and dynamic stability of the leg joints by developing the strength of the muscles around joints, and default force of the lower limbs. Other authors Hägglund, M., Waldén, M., Atroshi, I., 2009, have concluded that „proprioception exercises help to improve in rapid changes in the direction and strength of muscle and have a beneficial effect in recovery after trauma to the knee joint"

The fact that in the final testing the experimental group has better results compared to the control group proves us that the special training program we have used contained useful exercises and that the respective exercises number of repetitions was sufficient to generate significant effects. And other researchers (Olsen, O.E., Myklebust, G., et all., 2005, Waldén, M., Atroshi, I., et all., 2012; Gidu , D.V., Oltean, A., 2016) have shown that 15 minutes of proprioceptive training performed two times on week resulted in improving lower limb strength in woman soccer players.

\section{CONCLUSIONS}

The experimental group obtained better results in the final testing than the initial ones $(p<0,005)$.

The experimental group obtained significanttly better results compared to the control group in the final testing in both tests.

As a result of statistical analysis performed, we can consider that the working hypothesis was verified. 
"Mircea cel Batran" Naval Academy Scientific Bulletin, Volume XIX - 2016 - Issue 1 Published by "Mircea cel Batran" Naval Academy Press, Constanta, Romania // The journal is indexed in: PROQUEST / DOAJ / DRJI / JOURNAL INDEX / I2OR / SCIENCE LIBRARY INDEX / Google Scholar / Crossref / Academic Keys I ROAD Open Access / OAJI / Academic Resources / Scientific Indexing Services / SCIPIO

\section{BIBLIOGRAFY}

[1] Barton Straus, L., 2012, Female Teen Soccer Players in Neuromuscular Training Program Cut ACL Injury Risk by Two-Thirds, http://www.momsteam.com/anterior-cruciate-ligament/female-soccer-players-inneuromuscular-training-program-cut-ACL-injury-risk-two-thirds

[2] Chappell, J.D., Limpisvasti, O., 2008, Effect of a neuromuscular training program on the kinetics and kinematics of jumping tasks, Am J Sports Med., Jun; 36 (6): 1081-6

[3] Cocucci, R., Boni, R., 2005, I training propriocettivi, $\|^{\circ}$ convegno internazionale "Prevenzione e rieducazione dei traumi dello sportivo", 2 ottobre 2005, Verona, p.1-6.

[4] Coughlan, G., Caulfield, B., 2007, A 4-Week Neuromuscular Training Program and Gait Patterns at the Ankle Joint, J Athl Train. Jan-Mar; 42 (1): 51-59

[5] Gidu , D.V., Oltean, A., 2016, Benefits of the proprioceptive training in recovery after knee sprain theoretical grounds, Science, Movement and Health, Vol. XVI, ISSUE 1, 2016 January 2016, 16 (1): 69-73

[6] Gustavsson, A., Neeter, C., Thomee, P., Grävare Silbernagel, Auguston, J., Thomee, R., Karlsson, J., 2006, A test battery for evaluating hop performance in patients with an ACL injury and patients, who have undergone ACL reconstruction, Knee Surg Sports Traumatol Arthrosc (2006) 14: 778-788

[7] Hägglund, M., Waldén, M., Atroshi, I., 2009, Preventing knee injuries in adolescent female football players - design of a cluster randomized controlled trial [NCT00894595], BMC Musculoskelet Disord. 10: 75

[8] Myer, G.D. Ford, K.R., Palumbo, J.P., Hewett, T.E., 2005, Neuromuscular training improves performance and lower-extremity biomechanics in female athletes, Journal of Strength and Conditioning Research, 19 (1): 51-60

[9] Olsen, O.E., Myklebust, G., Engebretsen, L., Holme, I., Bahr, R., 2005, Exercises to prevent lower limb injuries in youth sports: cluster randomised controlled trial, BMJ. Feb 26; 330 (7489): 449.

[10] Waldén, M., Atroshi, I., Magnusson, H., Wagner, P., Hägglund, M., 2012, Prevention of acute knee injuries in adolescent female football players: cluster randomised controlled trial, BMJ. May 3; $344: e 3042$

[11] Zouita Ben Moussa,A., Zouita,S., Dziri,C., Ben Salah,F.Z., 2009, Single-leg assessment of postural stability and knee functional outcome two years after anterior cruciate ligament reconstruction, Annals of Physical and Rehabilitation Medicine, Volume 52, Issue 6, July 2009, Pages 475-484.

[12] http://www.my-personaltrainer.it/allenamento/allenamento-propriocettivo.html)

[13] http://www.scribd.com/doc/227803314/Prezentare-Pitesti-Ro\#scribd 